\title{
Dentists' Behavior of Preventive Measures toward COVID-19 transmission at Dental Clinics in Pekanbaru City
}

\author{
Oktavia Dewi, Nurlisis, M. Reyhan \\ Institute of Health Science Hang Tuah Pekanbaru, Riau, Indonesia \\ Email: dewitavia@yahoo.com, nurlisis@htp.ac.id, and Reyhan.dean96@gmail.com
}

\begin{tabular}{|c|c|}
\hline ARTICLE INFO & ABSTRACT \\
\hline $\begin{array}{l}\text { Date received : } 03 \\
\text { January } 2021 \\
\text { Revision date : } 02 \\
\text { February } 2021 \\
\text { Date received : } 01 \\
\text { March } 2021\end{array}$ & \multirow{2}{*}{$\begin{array}{l}\text { Background Dentist professions are the greatest risk of being } \\
\text { infected with Covid-19 virus. Dentists are very often exposed to } \\
\text { bioaerosol, which is produced during dental work. There were } 202 \\
\text { dentists in Indonesia who died due to exposure to the covid-19 } \\
\text { virus. Dentists' behavior and attitude in dealing with the Covid-19 } \\
\text { virus outbreak is very important in preventing transmission of the } \\
\text { virus their practice room. This study aims to analyze the behavior of } \\
\text { dentists to prevent covid transmission during dental treatment in } \\
\text { the practice room. This research was a qualitative research with an } \\
\text { exploratory approach. The research subjects were several dentists } \\
\text { practicing independently in Pekanbaru City who were selected by } \\
\text { purposive sampling. The data were collected by conducting in- } \\
\text { depth interviews and incidental observations when the dentist } \\
\text { performed treatment in the practice room. Data analysis was } \\
\text { performed using the theme design and data validity test using } \\
\text { source triangulation and data triangulation. All dentists have good } \\
\text { knowledge and attitudes in preventing the transmission of covid-19, } \\
\text { however, not all dentists have taken infection prevention measures } \\
\text { because they have not used personal protective equipment (PPE) } \\
\text { according to the standards recommended by the Indonesian } \\
\text { Association of Dentists (PDGI) and Indonesian Doctor Association } \\
\text { (IDI). This is due to inconvenience at work and limited costs. The } \\
\text { behavior of preventing the transmission of covid-19 carried out by } \\
\text { dentists in an independent practice room is not optimal. It is } \\
\text { expected that dentists wear level } 3 \text { personal protective equipment } \\
\text { and the government facilitates periodic swab checks and provides } \\
\text { vaccinations.. }\end{array}$} \\
\hline Practice room & \\
\hline
\end{tabular}

\section{INTRODUCTION}

Coronaviruses is a group of viruses that can cause disease in animals or humans. Some types of corona virus are known to cause airway infections in humans ranging from cold, coughs, to more serious ones such as Middle East Respiratory Syndrome (MERS) and Severe Acute Respiratory Syndrome (SARS). The most common symptoms of COVID-19 are fever, fatigue, and dry cough. Approximately 1 in 6 people affected by COVID-19 are seriously ill and have difficulty breathing, COVID-19 can transmit from human-to human through droplets from the nose or mouth that come out when COVID-19 patients coughs or exhales. These droplets then fall onto nearby objects and surfaces. People who touch these objects or surface and then touch their eyes, nose or mouth, may get infected with COVID-19.

Dentists are very often exposed to bioaerosol produced during dental treatment. There are 202 dentists in Indonesia who died from exposure to the covid-19 virus. ${ }^{3}$ The behavior of dentists facing the covid-19 virus outbreak is very instrumental to prevent the transmission of the virus in the practice room, Dentists must understand how the spread of

\begin{tabular}{ll}
\hline How to cite: & $\begin{array}{l}\text { Dewi, Oktavia et.al. (2021) Dentists' Behavior of Preventive Measures toward COVID-19 } \\
\text { transmission at Dental Clinics in Pekanbaru City, 2(3). } \\
\text { https://doi.org/10.46799/jsss.v2i3.132 }\end{array}$ \\
\hline E-ISSN: & $2721-5202$ \\
\hline Published by: & Ridwan Institute \\
\hline
\end{tabular}


covid-19, how to identify patients with this virus infection, and what protective measures should be taken during practice, to prevent transmission.

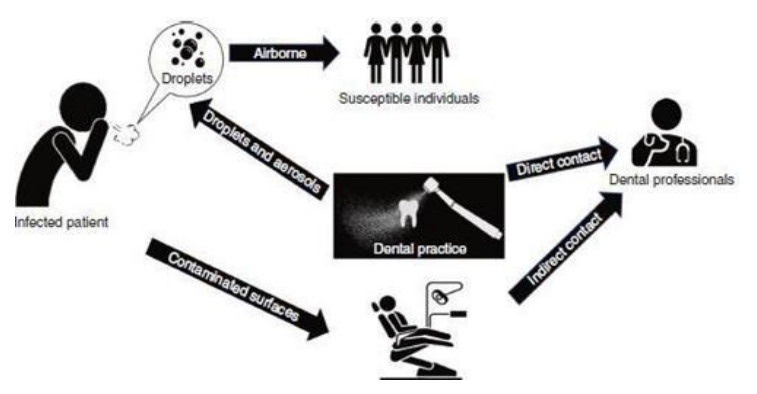

Figure .1.

how to transmit covid-19 in the dentist's practice room (Peng et al., 2020)

In figure 1 shows the flow of transmission of the virus covid-19 patients who have been infected with the virus and then producing aerosols that can transmit to dentists who do not use optimal personal protective equipment and contaminate the equipment and practice room, then will also transmit to the next patient. So that is the spread of covid-19 virus transmission in other communities.

\section{METHOD}

This research was descriptive qualitative research with an explorative approach. The research was conducted to find out the extent of knowledge, attitudes and actions of dentists in preventing the transmission of covid-19 in their practice room, so that researchers tried to understand more deeply about the problems felt by informants through in-depth interviews.

The informant consisted of the main informant and the supporting informant. The selection of informants was taken purposively in accordance with the principles of conformity and adequacy. Data collection techniques were conducted with in-depth interviews and literature searches related to dentist behavior towards the prevention of covid-19 transmission. From the data collected, a transcript of the data was then created that records all the data obtained as it was. The analysis was conducted using theme design and data validity test using source triangulation and data triangulation.

\section{RESULTS AND DISCUSSION}

In table 1 shows the characteristics of the dentist. The main informants are 3 people, the gender of all women and have been practicing for more than 15 years, while the supporting informant is the chairman of PDGI Riau with a 25-year practice.

Table 1

Characteristics of Informants

\begin{tabular}{cccccc}
\hline $\begin{array}{c}\text { Inform } \\
\text { ant } \\
\text { Code }\end{array}$ & Education & $\begin{array}{c}\text { Posi } \\
\text { tion }\end{array}$ & $\begin{array}{c}\text { Age } \\
\text { Main }\end{array}$ & $\begin{array}{c}\text { Gend } \\
\text { er }\end{array}$ & $\begin{array}{c}\text { Years of } \\
\text { Practice }\end{array}$ \\
$\begin{array}{c}\text { Informa } \\
\text { nt 1 (U1) }\end{array}$ & & $\begin{array}{c}\text { gove } \\
\text { rnm } \\
\text { ental }\end{array}$ & $\begin{array}{c}42 \\
\text { th }\end{array}$ & $\begin{array}{c}\text { Wom } \\
\text { an }\end{array}$ & 16 years \\
\hline $\begin{array}{c}\text { Main } \\
\text { Informa }\end{array}$ & S1-drg & gove & 52 & Wom & 25 years \\
nt 2 (U2) & & rnm & th & an & \\
\hline $\begin{array}{c}\text { Main } \\
\text { Informa }\end{array}$ & Si-drg & PNS & 51 & Wom & 26 years \\
nt 3 (U3) & & th & an & \\
\hline $\begin{array}{c}\text { Supporti } \\
\text { ng }\end{array}$ & S2-drg & Chair & 51 & Wom & 25 years \\
Informa & & man & th & an & \\
nt (P1) & & of & & & \\
& & PDGI & & & \\
& & Riau & & & \\
& & Regi & & & \\
\hline
\end{tabular}

(Source : Interview Results 2020)

From the results of in-depth interviews all informants knew that the pandemic that occurs at this time was caused by coronavirus, symptoms were fever with temperature $\geq 38$ degrees Celsius, cough, cold, sore throat and shortness of breath. and can be transmitted by aerosol through inhaled droplets or contact with patients whose hands touch the nose or eyes. All informants also knew that transmission of this virus could be prevented by using personal protective equipment when treating patients. and very understand that their job as dentists is a very risky job to being infected with this covid-19 disease.

Based on the results of the study, all dentists agreed with the covid-19 protocol in order to prevent the transmission of coronavirus. This is stated by reason: (1) it is no longer difficult to invite the patient to take precautions on him in the practice room such as wearing a mask, washing hands with soap 
or using a hand sanitizer and keeping a distance in the practice room; (2) the dentist $\mathrm{him} /$ herself is more disciplined in using personal protective equipment (PPE) than before covid-19 pandemic for fear of getting infected; (3) cost problems, although dentists are a little troubled by the increasing costs for the procurement of complete equipment and PPE and mostly charge patients with the addition of service money but still within the limits of fairness and ability of patients to pay. Based on the results of the interview, the addition of service money varies in size, ranging from not adding a penny, the addition of ten thousand IDR, a hundred thousand IDR to additional $10 \%$ of service applied before the covid-19 pandemic, as quoted below:

"Raised but a little... Rp.10.000... a lot of spending to buy disinfectant .....PPE ...... examination equipment is multiplied.... minimized the transmission that can be done (IU1)" or "Indeed the cost during the pandemic covid-19 is increased and there is no additional cost of fixed patient services before covid-19"(IU2) or "Services raised $10 \%$ for the purchase of $1 \mathrm{x}$ disposable tools per 1 patient" (IU3).

Based on the results of interviews with several dentists it is known that all dentists took precautions against every patient who came to visit by doing the following: (1) most dentist practices provided sinks for hand washing using soap ;(2) all dentists obliged their patients and companions who came using masks; (3) some dentists conducted screening such as temperature checks, general disease history and previous trips; (4) all dentists had their patients gargle with betadine solution and (5) gave instructions on covid protocol such as always washing hands and wearing masks, using ethics if coughing and sneezing and keeping a distance. Not all dentists did temperature checks with the base and tools used have been damaged and have not had time to replace them and other anamneses were not done because some patients object to tell the symptoms of other diseases and wanted to do dental treatment only. As the following interview excerpt:

"Sometimes asked .. sometimes not ..... almost all patients say no previous illness or fever even just told to do dental treatment only. For fever sometimes patients do not want to tell ... patient objected to be asked the history of previous covid-19 infection ... No temperature measurement is performed. Patients are reluctant to seeing doctor with PPE clothes and feel uncomfortable.. especially pediatric patients" (IU1).

In addition, almost all dentists did some activities and increased food supply to increase endurance such as exercise, sunbathing, inhaling eucalyptus oil, consuming vitamins and fruits and adequate rest by reducing their hours of practice.

SARS-CoV-2, the virus that causes COVID-19 allows transmission in dentistry practice due to the possibility of inhalation of aerosols or droplets containing viruses or direct contact with mucous membranes, oral fluids, and instruments and surfaces contaminated with the virus. (Vickers, 2017) According to (Sari, Afriza, \& Roesnoer, 2014), the lack of knowledge of dentists towards infection control, it is stated that $48 \%$ of respondents have low knowledge and $52 \%$ of respondents have high knowledge of infection control. Based on the results of the study, respondents showed better knowledge and understanding about the prevention of covid19 transmission. This may be because there has been a lot of information circulating about how to prevent the transmission of covid 19. Most dentists agree with government regulations imposed by health protocols to prevent covid. Based on a survey conducted by North American Dental Group (NADG), the attitude of patients to see a dentist has changed during the COVID-19 pandemic. Among the findings stated $64 \%$ believe in taking treatment to a dentist's practice, because they believe dentists know how to prevent the spread of COVID-19. Thanks to the dental association, there is clear information on preventive procedures during dentistry practice during COVID-19. As many as $60 \%$ of respondents said they were comfortable visiting the dentist for regular cleaning or checkups, this doubled from the previous month (F.N, 2020).

Dentistry can cause aerosols from saliva or blood from patients, especially when using ultrasonic scalers, high speed handpieces and three-way syringes. Aerosols containing various microorganisms that can be inhaled and enter the respiratory tract of patients as well as dentists and other officers (Liasari \& Lesmana, 2020). In the case of COVID-19 positive patients, if dental 
treatment is performed, especially scaling with ultrasonic scalers can cause saliva containing the virus to be isolated and spread and contaminate the dental unit. The virus can last up to 3 hours in aerosols and can be detected on the surface of objects for up to 72 hours. This leads to a high risk of dental health workers being exposed (Passarelli, Rella, Manicone, Garcia-Godoy, \& D'Addona, 2020). The spread of COVID- 19 virus occurs not only in patients who already have symptoms, but also asymptomatic patients (Chang, Xu, Rebaza, Sharma, \& Cruz, 2020). Based on several references to measures that can be taken in dentist practice by conducting patient management and prevention of nosocomial infections prior to dental treatment, the use of personal protective equipment for dentists and teams, precautions during dental care, and environmental sanitation /practice room (Ather, Patel, Ruparel, Diogenes, \& Hargreaves, 2020);(Passarelli et al., 2020); (Peditto, Scapellato, Marcianò, Costa, \& Oteri, 2020).

Based on the results of the study, the dentist's action against the prevention of covid-19 transmission has been good even though it was not optimal. During the pandemic, patient management was necessary and prevention of transmission. Patients who come to the clinic need to be restricted to avoid the spread of the virus between patients (Lai, Tang, Chau, Fung, \& $\mathrm{Li}, 2020)$. Restrictions on the number of patients coming to the clinic can be done by means of screening.

Screening of patients by phone or other communication media needed to be done so that patients can be grouped. Remote screening or tele-screening can be a questionnaire containing questions asked to patients, including questions about whether or not contact with others who are covid-19 patients, having traveled to areas with high incidence rates, or whether or not there are symptoms of fever and cough (Ather et al., 2020); Ge et al., 2020; (Lai et al., 2020). Likewise, in the clinic waiting room, it needs to be arranged in such a way that there is a minimum distance of 1 meter between patients (Vickers, 2017); (Rahman \& Bahar, 2020).

The waiting room should be facilitated with hand sanitizer. The patient is checked for body temperature and required to wear a surgical mask. The use of this surgical mask complies with level 1 personal protective equipment standards according to the Classification of the American Society for Testing and Materials (ASTM). (ASTM Standards \&COVID-19, no date) Surgical masks can withstand $97.14 \%$ of viruses from aerosols. (Lustig et al., 2020).

\section{CONCLUSION}

Dentist knowledge about covid-19 was good, all dentists had knowledge about the causes of covid-19, symptoms of disease if exposed to covid-19, consequences, ways of transmission and what measures were taken to prevent transmission. The dentist's attitude towards preventing the transmission of covid19 strongly agrees with the covid-19 protocol. Prevention behavior of covid-19 transmission conducted by dentists in self-service practice room was not optimal, it was expected that dentists wear level 3 personal protective equipment and the government facilitates regular swab examinations and vaccinations.

\section{REFERENCES}

Ather, Amber, Patel, Biraj, Ruparel, Nikita B., Diogenes, Anibal, \& Hargreaves, Kenneth M. (2020). Coronavirus disease 19 (COVID-19): implications for clinical dental care. Journal of Endodontics, 46(5), 584-595. Google Scholar

Chang, De, Xu, Huiwen, Rebaza, Andre, Sharma, Lokesh, \& Cruz, Charles S. Dela. (2020). Protecting health-care workers from subclinical coronavirus infection. The Lancet Respiratory Medicine, 8(3), e13. Google Scholar

F.N, Nia. (2020). Survei sikap pasien terhadap dokter gigi. Buletin Cobra Dental. Google Scholar

Lai, Tracy H. T., Tang, Emily W. H., Chau, Sandy K. Y., Fung, Kitty S. C., \& Li, Kenneth K. W. (2020). Stepping up infection control measures in ophthalmology during the novel coronavirus outbreak: an experience from Hong Kong. Graefe's Archive for Clinical and Experimental Ophthalmology, 258(5), 1049-1055. Google Scholar 
Liasari, Ira, \& Lesmana, Hans. (2020). Studi Literatur: Pencegahan Penyebaran SarsCov-2 Pada Praktik Kedokteran Gigi. Media Kesehatan Gigi: Politeknik Kesehatan Makassar, 19(1). Google Scholar

Lustig, Steven R., Biswakarma, John J. H., Rana, Devyesh, Tilford, Susan H., Hu, Weike, Su, Ming, \& Rosenblatt, Michael S. (2020). Effectiveness of common fabrics to block aqueous aerosols of virus-like nanoparticles. ACS Nano, 14(6), 7651-7658. Google Scholar

Passarelli, Pier Carmine, Rella, Edoardo, Manicone, Paolo Francesco, GarciaGodoy, Franklin, \& D'Addona, Antonio. (2020). Minireview Highlight article. Experimental Biology and Medicine, 245, 940-944. Google Scholar

Peditto, Matteo, Scapellato, Simone, Marcianò, Antonia, Costa, Paola, \& Oteri, Giacomo. (2020). Dentistry during the COVID-19 epidemic: An Italian workflow for the management of dental practice. International Journal of Environmental Research and Public Health, 179), 3325. Google Scholar
Peng, Xian, Xu, Xin, Li, Yuqing, Cheng, Lei, Zhou, Xuedong, \& Ren, Biao. (2020). Transmission routes of 2019-nCoV and controls in dental practice. International Journal of Oral Science, 12(1), 1-6. Google Scholar

Rahman, Shaila, \& Bahar, Tamanna. (2020). COVID-19: The new threat. International Journal of Infection, 71 ). Google Scholar

Sari, Intan Puspita, Afriza, Dhona, \& Roesnoer, Masra. (2014). Hubungan Antara Pengetahuan Tentang Infeksi Silang Dengan Penatalaksanaan Pencegahan Infeksi. B-Dent: Jurnal Kedokteran Gigi Universitas Baiturrahmah, 1(1), 30-37. Google Scholar

Vickers, Neil J. (2017). Animal communication: when i'm calling you, will you answer too? Current Biology, 2714), R713-R715. Google Scholar

\section{Oktavia Dewi, Nurlisis, M. Reyhan (2021) \\ First publication right: \\ Journal of Social Science (JSS)}

Copyright holder:

This article is licensed under: 